\title{
Interleukin gene polymorphisms in pneumoconiosis
}

\author{
SIMONE HELMIG, MARTIN GROSSMANN, JELENA WÜBBELING and JOACHIM SCHNEIDER
}

Institute and Polyclinic for Occupational and Social Medicine, Justus-Liebig University, D-35392 Giessen, Germany

Received February 1, 2012; Accepted March 2, 2012

DOI: $10.3892 / \mathrm{ijmm} .2012 .996$

\begin{abstract}
Inhaled asbestos fibres are known to cause inflammation processes with the result of lung or pleural fibrosis and malignancies. Interleukins (IL), such as IL-1 $\beta$, IL-6 and IL-10, have various functions in the regulation of the inflammatory response and in proliferative processes after inhalation of silica dust and can, therefore, influence the pathogenesis of asbestosinduced fibrosis and carcinogenesis. Polymorphisms within these genes may be associated with susceptibility to silica and asbestos-induced lung diseases. Thus, IL-1 $\beta$, IL- 6 and IL-10 polymorphisms were examined to determine an association with asbestos or silica-induced fibrosis or malignancies. Association studies were performed in 1180 individuals, using control subjects $(n=177)$, fibrosis patients $(n=605)$, lung cancer (LC) patients $(n=364)$ and malignant mesothelioma (MM) patients $(\mathrm{n}=34)$. IL-1 $\beta$ (C-511T; C+3954T), IL-6 (G-174C) as well as IL-10 (G-1082A) polymorphisms were investigated. Compared to a healthy (control) group, a higher risk was seen for malignant mesothelioma patients in all investigated polymorphisms. The IL-6 -174C allele showed a tendency towards a higher risk for fibrosis or asbestos-induced lung cancer $\left(\mathrm{OR}_{\text {asbestosis }}, 1.338 ; 95 \% \mathrm{CI}, 0.71-2.53\right.$; $\mathrm{OR}_{\text {silicosis }}, 1.226$; 95\% CI, 0.54-2.81; OR fibrosis other aetiology, $1.313 ; 95 \%$ CI, 0.58-2.98 and $\left.\mathrm{OR}_{\mathrm{LC} \text { asbestos }}, 2.112 ; 95 \% \mathrm{CI}, 0.75-5.92\right)$. The IL-10 -1082A carrier seemed to be at higher risk for silicosis $\left(\mathrm{OR}_{\text {silicosis }}\right.$, 2.064; 95\% CI, 0.78-5.49) but not for asbestosis. In summary, this study did not reveal sufficient evidence for a significant association of the investigated interleukin polymorphisms with asbestos or silica-induced diseases in the population studied.
\end{abstract}

\section{Introduction}

Inhaled asbestos fibres are known to cause progressive lung or pleural fibrosis and malignancies, such as lung cancer or

Correspondence to: Dr Simone Helmig, Institute and Polyclinic for Occupational and Social Medicine, Justus-Liebig University, Aulweg 129, D-35392 Giessen, Germany

E-mail: simone.helmig@arbmed.med.uni-giessen.de

Abbreviations: BKV, occupational disease regulation; $\mathrm{PAH}$, polycyclic aromatic hydrocarbons; LC, lung cancer; LPS, lipopolysaccharide; OR, odds ratio; CI, confidence interval; PY, pack year; MM, malignant mesothelioma

Key words: interleukin gene polymorphism, asbestos, silica, lung fibrosis, lung cancer, single-nucleotide polymorphisms, cytokines diffuse malignant mesothelioma (1). Interindividual differences might play a crucial role in the outcome and severity of asbestos diseases (2). Inflammatory processes are of general importance in the pathogenesis of asbestosis and also in silicosis, as they are driven by chronic inflammation due to inhaled fibres and particles (3). The inhalation of asbestos or silica leads to interleukin-1 $\beta$ (IL-1 $\beta$ ) secretion, which plays a key role in the pathogenesis of occupational-related pneumoconiosis $(4,5)$. IL- $1 \beta$ is a pro-inflammatory cytokine with wide ranging effects on gene expression, such as upregulating cytokines and tissue remodelling enzymes $(6,7)$. Chronic overexpression of IL- $1 \beta$ may also contribute to the growth, vascularisation and metastasis of malignant tumours (8-10).

The IL-6 multifunctional cytokine has the potential of initiating a fibrogenic response after asbestos exposure (11). As a result of the fibres, lung epithelial cells release IL-6, which in turn stimulates lung fibroblast DNA synthesis (12). Several studies have reported an involvement of IL-6 in the pathogenesis of inflammatory diseases such as coal workers' pneumoconiosis (CWP) (13) rheumatoid arthritis (14), chronic arthritis (15) and psoriasis (16).

Single-nucleotide polymorphisms (SNPs) in regulatory regions of cytokine genes have been associated with susceptibility to a number of complex disorders (17-19). The $\mathrm{T}$ alleles of the IL-1 $\beta$ C+3954T (rs1143634) and C-511T (rs16944) polymorphisms have been shown to correlate with higher IL-1 $\beta$-protein levels in vitro $(20,21)$. On the other hand, the $\mathrm{C}$ allele of the IL-6 G-174C polymorphism (rs1800795) was found to be associated with significant lower levels of plasma IL-6 (22).

IL-10 is an important immunosuppressor cytokine, controlling the balance between inflammatory and humoral response by inhibiting the release of pro-inflammatory mediators such as IL-1 $\beta$ and IL-6. Physiologically it is produced after proinflammatory mediators and, therefore, plays a role in limiting an excessive immune response and collateral damage $(23,24)$. Interindividual variations of IL-10 levels (mRNA and serum protein levels) are genetically controlled by polymorphic variants present at the gene promoter. The $\mathrm{G}$ allele at position -1082 seems to be the most important genetic factor in the regulation of IL-10 levels (25).

In the present study, we investigated the distribution of genotype frequencies of proinflammatory mediator polymorphisms (IL-1 $\beta$ C+3954T, IL-1 $\beta$ C-511T and IL-6 G-174C) and the anti-inflammatory cytokine IL-10 polymorphism (IL-10 G-1082A) in patients with asbestos- or silica-induced fibrosis or malignancies. 
Table I. Discrimination between different kinds of exposure.

\begin{tabular}{|c|c|c|c|}
\hline Diseases & $\mathrm{N}$ & Definition & Diagnosis criteria (Ref.) \\
\hline Asbestosis & 389 & $\begin{array}{l}\text { BKV } 4103 \text { according to the German } \\
\text { list of occupational diseases }\end{array}$ & $\begin{array}{l}\text { Caused by asbestos dust; } \\
\text { diagnosis criteria ( } 48 \text { ) }\end{array}$ \\
\hline Silicosis & 161 & $\begin{array}{l}\text { BKV } 4101 \text { according to the German } \\
\text { list of occupational diseases }\end{array}$ & $\begin{array}{l}\text { Caused by silica dust; } \\
\text { diagnosis criteria (29) }\end{array}$ \\
\hline Lung interstitial fibrosis & 55 & & No relevant exposure to asbestos \\
\hline Asbetos-related lung cancer & 49 & $\begin{array}{l}\text { BKV } 4105 \text { according to the German } \\
\text { list of occupational diseases }\end{array}$ & Diagnosis criteria (49) \\
\hline Diffuse malignant mesothelioma & 34 & $\begin{array}{l}\text { BKV } 4105 \text { according to the German } \\
\text { list of occupational diseases }\end{array}$ & Caused by asbestos dust \\
\hline Lung cancer & 315 & & No relevant exposure to asbestos \\
\hline
\end{tabular}

Several groups of patients suffering from lung fibrosis or lung cancer were created and compared to a non-exposed control group. BKV, German classification system of occupational diseases.

\section{Materials and methods}

Subjects. The study population consisted of a total of 1180 German individuals. All subjects included in this study were interviewed using a questionnaire to obtain information on lifestyle (including a lifetime history of tobacco use) and occupational history. According to their reported smoking habits, patients were classified into smokers, ex-smokers or never smokers. Individual smoking pack years (PY) were calculated. One PY was defined as smoking 20 cigarettes daily over one year. Written informed consent was obtained from all patients before inclusion in the study.

The control group comprised of 177 unrelated, healthy subjects without known diseases and without any exposure to carcinogenic (or fibrogenic) agents at the work place. Any subject with diseases related to potential tissue fibrosis (e.g. diabetes, chronic lung disease) or with benign or malignant tumors were excluded.

The lung fibrosis patients group contained 605 subjects. Only subjects with confirmed diagnosis of lung fibrosis, according to the WHO criteria $(26,27)$ were included. The lung cancer patient group contained 364 and the malignant mesothelioma group contained 34 patients. Only subjects with histological confirmed diagnosis of primary lung cancer or diffuse malignant mesothelioma, according to the WHO criteria (28), were included.

Diagnosis of pulmonary diseases was based on physical examination, haematological, biochemical and immunological laboratory analyses and pulmonary function tests. All patients underwent diagnostic procedures, including X-ray examination interpreted according to the International Labour Office (ILO) Classification of Radiographs of Pneumoconiosis (29).

To allow further discrimination between different kinds of exposure, several groups of patients suffering from fibrosis or lung cancer were created and compared to a non-exposed control group (Table I). In a second evaluation step, the asbestosis group was further subdivided into groups considering the expansion and severity code of fibrosis. These groups were established using chest X-ray findings according to the ILO Classification of Radiographs of Pneumoconiosis (29).
Chest $X$-ray findings. Chest $\mathrm{X}$-rays were reviewed and graded according to the ILO 2000 classification. According to the ILO standard X-rays, three profusions (1,2 and 3$)$ and the six size and shapes of the opacities ( $p, q, r$ for rounded, $s, t, u$ for irregular, and A, B and C for large opacities) were coded. Asbestos-related abnormalities were classified as asbestosis (parenchymal changes) or as asbestos-induced pleural diseases (Table II) (29). Diffuse pleural thickening without parenchymal bands were only observed in adipose patients and as such were attributed to subpleural fat. The Ethics Committee of the University Hospital, Giessen, Germany, approved the study (AZ:75/06).

Real-time PCR and polymorphism detection. Whole blood ( $3 \mathrm{ml}$ ) samples were collected by venipuncture in tubes containing EDTA (Sarstaedt, Nümbrecht, Germany). Genomic DNA was isolated from whole blood using the Versagene ${ }^{\mathrm{TM}}$ DNA purification kit (Gentra Systems, Minneapolis, MN, USA). Detection of the polymorphisms was performed by rapid capillary PCR, with melting curve analysis, using fluorescencelabelled hybridisation probes in a LightCycler System (Roche Diagnostics, Mannheim, Germany). The PCR primers as well as the fluorescent-labelled detection probes were synthesized by TIB Molbiol (Berlin, Germany) (Table III). The reaction mixture (20 $\mu \mathrm{l})$ for IL-1 $\beta \mathrm{C}+3954 \mathrm{~T}$ comprised $2 \mu \mathrm{l}$ of forward primer $(10 \mu \mathrm{M}), 1 \mu 1$ of reverse primer $(10 \mu \mathrm{M})$ and $0.4 \mu 1$ of each probe $(10 \mu \mathrm{M}), 1.2 \mu 1 \mathrm{MgCl}_{2}(25 \mathrm{mM}), 2 \mu 1$ FastStart DNA Master Hybridization Probes (Roche Diagnostics) and $2 \mu 1$ DNA. The reaction mixture ( $20 \mu 1)$ for IL-6 and IL-10 comprised $0.6 \mu 1$ of each primer $(10 \mu \mathrm{M})$ and $0.4 \mu 1$ of each probe $(10 \mu \mathrm{M}), 10 \mu \mathrm{l}$ ABgene QPCR Capillary Master Mix (Thermo Fisher, Dreieich, Germany) and $2 \mu 1$ DNA. Annealing temperatures were $60^{\circ} \mathrm{C}$ for IL- $1 \beta \mathrm{C}+3954 \mathrm{~T}, 57^{\circ} \mathrm{C}$ for IL-6 G-174C and $63^{\circ} \mathrm{C}$ for IL-10 G-1082A polymorphism. The melting curves were generated to obtain melting temperatures. PCR contamination was checked by the inclusion of negative control, where cDNA was replaced by water.

Detection of the IL-1 $\beta$ C-511T polymorphisms was performed by restriction fragment length analysis (RFLA). The reaction mixture $(22 \mu \mathrm{l})$ for the PCR consisted of $1 \mu \mathrm{l}$ 
Table II. X-ray classification of asbestosis and pleural plaques.

\begin{tabular}{ll}
\hline Grade & \multicolumn{1}{c}{ Classification group } \\
\hline $\begin{array}{l}\text { Classification of parenchymal changes } \\
<1 / 0\end{array}$ & No definite lung fibrosis \\
$1 / 1$ and $1 / 2$ & Beginning lung fibrosis \\
$2 / 1,2 / 2$ and $2 / 3$ & Moderate lung fibrosis \\
$3 / 2,3 / 3$ and $3 /+$ & Severe lung fibrosis \\
Classification of pleural changes \\
0 & No definite pleural plaques \\
1 & $<1 / 4$ of lateral thoracic wall \\
2 & $1 / 4-1 / 2$ of lateral thoracic wall \\
3 & $>1 / 2$ of lateral thoracic wall \\
Hyalinosis & Costophrenic obliteration; diffuse \\
complicata & pleural thickening; pleuro-parenchymal \\
& fibrous strand ('crow feet')
\end{tabular}

The groups were established using chest X-ray findings according to the International Labour Office Classification of Radiograhs of Pneumoconiosis (29).

of each primer (TIB Molbiol) (Table III), $1 \mu \mathrm{l}$ Q-solution, $2 \mu 1 \mathrm{10X}$ buffer, $2 \mu 1 \mathrm{MgCl}_{2}, 1 \mu \mathrm{l}$ HotstarTaq $^{\circledR}$ Plus (all from Qiagen, Hilden, Germany) $0.2 \mu \mathrm{l}$ dNTPs (Fermentas, St. Leon-Rot, Germany) and $2 \mu \mathrm{l}$ DNA. Annealing temperatures in 40 cycles was $58^{\circ} \mathrm{C}$. As a restriction enzyme AvaI (New England Biolabs, Ipswich, MA, USA) was used. Results were visualised by agarose gel electrophoresis.

Statistical analysis. The odds ratios (OR) and confidence intervals (CI) assessed the association between genotype distribution and patient status. The OR and 95\% CI were used as an estimate of the risk in all cases and were calculated by unconditional logistic regression. Adjustments for age, gender and tobacco smoking (PY) were computed to estimate the association between certain genotypes and diseases. Current smokers at the time of diagnosis were considered smokers. Ex-smokers were all the people who had ever smoked. Information was collected on the usual number of cigarettes smoked per day, the age at which the subject started smoking and, if the person was an ex-smoker, the age at which the subject stopped smoking. PY were calculated for the cumulative cigarette smoking. The smokers were stratified by the PY values. All statistical analyses were performed using the statistical software package, SSPS 17.0 (SPSS Inc., Chicago, IL, USA). Allelic and genotype frequencies were obtained by direct counting. The Hardy-Weinberg equilibrium was assessed by a $\chi^{2}$ test with 2 degrees of freedom. Allelic and genotype frequencies in patient and control groups were compared using a $2 \times 2$, contingency table and a $\chi^{2}$ test or the 2-tailed Fisher's exact test when the number of expected cases was too low. The level of significance was set at $\mathrm{P}<0.06$.

\section{Results}

More smokers or ex-smokers were present in the patient (81\%) compared to the control (42\%) group. The lung cancer patient group (91\%) but not the malignant mesothelioma group (42\%) included more smokers when compared to the controls (Table IV). The mean age of the control group was 39.2 years (range 20-76) and 67.5 years (range 29-91) for all the cases.

Clinical manifestation of IL-6 G-174C polymorphisms. The frequency of the IL-6 (-174) C allele in the control group as well as in the patients group was 0.45 . OR analyses were performed for the genotype $\mathrm{G}-174 \mathrm{G}$ vs. the genotypes carrying at least one C allele (G-174C or C-174C). Data was adjusted for PY, age (years) and gender.

Table III. Primer and probe sequences for interleukin polymorphisms.

\begin{tabular}{|c|c|c|c|}
\hline Gene & SNP & Primer & Primer sequence $5^{\prime} \rightarrow 3^{\prime}$ \\
\hline \multirow[t]{7}{*}{$\mathrm{IL}-1 \beta$} & $+3954(\mathrm{C} \rightarrow \mathrm{T})$ & Forward & 5'-CCTGCCCTTCTGATTTTATACC-3' \\
\hline & & Reverse & 5'-CAGGATGTTTCCATTTACCTTG-3' \\
\hline & & Anchor & TCGTGCACATAAGCCCTCGTTATCCC-FL \\
\hline & & $+3954(\mathrm{~T})$ & 640-TGTGTCAAAGAAGATAGGTTCTGAAA-p \\
\hline & $-511(\mathrm{C} \rightarrow \mathrm{T})$ & Forward & 5'-TGGCATTGATCTGGTTCATC-3' \\
\hline & & Reverse & 5'-GTTTAGGAATCTTCCCACTT-3' \\
\hline & & Enzyme & Aval \\
\hline \multirow[t]{4}{*}{ IL-6 } & $-174(\mathrm{G} \rightarrow \mathrm{C})$ & Forward & 5'-TTACTCTTTGTCAAGACATGCCA-3' \\
\hline & & Reverse & 5'-ATGAGCCTCAGACATCTCCAG-3' \\
\hline & & Anchor & AGCTGCACTTTTCCCCCTAGT-Fl \\
\hline & & $-174(\mathrm{G})$ & 640-GTGTCTTGCGATGCTAAAGGA-p \\
\hline \multirow[t]{4}{*}{ IL-10 } & $-1082(\mathrm{G} \rightarrow \mathrm{A})$ & Forward & 5'-CTCGCTGCAACCCAACTGGC-3' \\
\hline & & Reverse & 5'-ATGGGGTGGAAGAAGTTGAA-3' \\
\hline & & Anchor & GGATAGGAGGTCCCTTACTTTCCTCTTACC-Fl \\
\hline & & $+3954(\mathrm{G})$ & 640-СССТАСТТСССССТСССААА-р \\
\hline
\end{tabular}


Table IV. Demographic and disease parameters of controls and patients.

\begin{tabular}{|c|c|c|c|c|c|}
\hline & \multirow[b]{2}{*}{$\mathrm{n}$} & \multicolumn{3}{|c|}{ Age (years) } & \multirow{2}{*}{$\frac{\text { Smoking habit (\%) }}{\text { Smoker/ex-smoker }}$} \\
\hline & & Mean & Range & Median & \\
\hline Control total & 177 & 39.19 & $20.0-75.5$ & 34.9 & 58.2 \\
\hline Patient total & 1003 & 67.46 & $29.2-91.2$ & 68.8 & 81 \\
\hline Lung fibrosis & 605 & 68.18 & $29.2-91.2$ & 69.3 & 77 \\
\hline Silicosis (BKV 4101) & 161 & 70.47 & $40.3-88.9$ & 71.5 & 80.7 \\
\hline Asbestosis (BKV 4103) & 389 & 67.89 & $45.7-91.2$ & 68.6 & 77.1 \\
\hline Lung fibrosis of other aetiology & 55 & 63.5 & $29.2-82.1$ & 63.8 & 65.5 \\
\hline Malignant mesothelioma (BKV 4105) & 34 & 66.6 & $34.3-83.9$ & 68.2 & 44.1 \\
\hline Lung cancer & 364 & 66.6 & $34.3-83.9$ & 68.2 & 90.9 \\
\hline Asbestos induced lung cancer (BKV 4104) & 49 & 66.9 & $50.4-80.9$ & 67.4 & 98 \\
\hline Lung cancer of other aetiology & 315 & 66.5 & $34.3-83.9$ & 68.3 & 89.8 \\
\hline
\end{tabular}

Table V. Adjusted odds ratio of IL-6 G-174C polymorphisms.

\begin{tabular}{|c|c|c|c|c|c|c|}
\hline \multirow[b]{2}{*}{ Diagnosis } & \multirow[b]{2}{*}{$\mathrm{n}$} & \multicolumn{2}{|c|}{ Genotype, n (\%) } & \multicolumn{3}{|c|}{ Multivariate analysis } \\
\hline & & GG & $\mathrm{GC}$ or $\mathrm{CC}$ & OR & $95 \% \mathrm{CI}$ & p-value \\
\hline Lung fibrosis & 605 & $213(35.2)$ & $392(64.8)$ & 1.307 & $0.725-2.356$ & 0.373 \\
\hline Silicosis (BKV 4101) & 161 & $56(34.8)$ & $105(65.2)$ & 1.226 & $0.535-2.809$ & 0.63 \\
\hline Asbestosis (BKV 4103) & 389 & $138(35.5)$ & $251(64.5)$ & 1.338 & $0.708-2.532$ & 0.37 \\
\hline Lung asbestosis (BKV 4103) & 122 & $37(30.3)$ & $85(69.7)$ & 1.966 & $0.823-4.698$ & 0.128 \\
\hline $1 / 1$ and $1 / 2$ ILO & 66 & $19(28.8)$ & $47(71.2)$ & 2.288 & $0.798-6.564$ & 0.124 \\
\hline $2 / 1,2 / 2$ and $2 / 3$ ILO & 46 & $15(32.6)$ & $31(67.4)$ & 1.45 & $0.524-4.013$ & 0.475 \\
\hline $3 / 2,3 / 3$ and $3 /+$ ILO & 9 & $3(33.3)$ & $6(66.7)$ & 1.97 & $0.19-20.45$ & 0.57 \\
\hline Lung fibrosis of other aetiology & 55 & $19(34.5)$ & $36(65.5)$ & 1.313 & $0.579-2.978$ & 0.514 \\
\hline Malignant mesothelioma & 34 & $9(26.5)$ & $25(73.5)$ & 1.918 & $0.675-5.450$ & 0.222 \\
\hline Lung cancer (LC) & 364 & $129(35.4)$ & $235(64.6)$ & 1.091 & $0.574-2.074$ & 0.79 \\
\hline Asbestos induced LC (BKV 4104) & 49 & $16(32.7)$ & $33(67.3)$ & 2.112 & $0.754-5.916$ & 0.155 \\
\hline LC of other aetiology & 315 & $113(35.9)$ & $202(64.1)$ & 1.002 & $0.521-1.926$ & 0.995 \\
\hline
\end{tabular}

Data adjusted for the pack years (PY), gender and age (years) were used to calculate the odds ratios (OR) for the IL-6 G-174C polymorphism in patients of the investigated groups compared to the healthy controls. OR analyses were performed for the more frequent genotypes $(\mathrm{G}-174 \mathrm{G})$ vs. the genotypes carrying at least one of the less frequent (C) allele (G-174C or C-174C).

This analysis revealed that patients carrying at least one C allele of the IL-6 -174 polymorphism were at higher risk for fibrotic lung diseases $\left(\mathrm{OR}_{\text {asbestosis }}, 1.338\right.$; 95\% CI, 0.71-2.53; $\mathrm{OR}_{\text {silicosis }}, 1.226 ; 95 \% \mathrm{CI}, 0.54-2.81$ and $\mathrm{OR}_{\text {fibrosis other aetiology }}$, 1.313 ; 95\% CI, 0.58-2.98). Additionally higher risk were revealed for malignant mesothelioma $\left(\mathrm{OR}_{\mathrm{MM}}, 1.918 ; 95 \% \mathrm{CI}\right.$, $0.68-5.45)$ and asbestos-induced lung cancer $\left(\mathrm{OR}_{\mathrm{LC}}\right.$ asbestos, 2.112; 95\% CI, 0.75-5.92) but not for lung cancer of other aetiology $\left(\mathrm{OR}_{\mathrm{LC} \text { other aetiology }}, 1.00 ; 95 \% \mathrm{CI}, 0.52-1.93\right)$ (Table V).

Clinical manifestation of IL-10 G-1082A polymorphisms. The frequency of the IL-10 (-1082) G-allele was 0.47 in the control and in the patient group. The OR analyses were performed for the genotype G-1082G vs. the genotypes carrying at least one
A allele (G-1082A or A-1082A). Data was adjusted for PY, age (years) and gender. This analysis revealed that patients carrying at least one A allele of the IL-10 -1082 polymorphism were at higher risk for silicosis $\left(\mathrm{OR}_{\text {silicosis }}, 2.064 ; 95 \% \mathrm{CI}, 0.78-5.49\right)$ but not for asbestosis $\left(\mathrm{OR}_{\text {asbestosis }}, 0.986 ; 95 \% \mathrm{CI}, 0.48-2.03\right)$ or fibrosis of other aetiology $\left(\mathrm{OR}_{\text {fibrosis other aetiology }}, 0.903 ; 95 \% \mathrm{CI}\right.$, 0.37-2.23). A higher risk was revealed for malignant mesothelioma $\left(\mathrm{OR}_{\mathrm{MM}}, 1.726\right.$; $\left.95 \% \mathrm{CI}, 0.54-5.51\right)$ (Table $\left.\mathrm{VI}\right)$.

Clinical manifestation of $I L-1 \beta C+3954 T$ and $I L-1 \beta C-511 T$ polymorphisms. The frequency of the less frequent IL-1 $\beta$ $(+3954) \mathrm{T}$ allele in the control group was 0.26 and in the patient group 0.25 . The frequency of the less frequent IL-1 $\beta(-511)$ $\mathrm{T}$ allele was 0.31 in the control as well as in the patient group. 
Table VI. Adjusted odds ratio of IL-10 G-1082A polymorphisms.

\begin{tabular}{|c|c|c|c|c|c|c|}
\hline \multirow[b]{2}{*}{ Diagnosis } & \multirow[b]{2}{*}{$\mathrm{n}$} & \multicolumn{2}{|c|}{ Genotype, n (\%) } & \multicolumn{3}{|c|}{ Multivariate analysis } \\
\hline & & GG & GA or AA & OR & $95 \% \mathrm{CI}$ & p-value \\
\hline Lung fibrosis & 605 & $126(20.8)$ & $479(79.2)$ & 1.144 & $0.586-2.235$ & 0.693 \\
\hline Silicosis (BKV 4101) & 161 & $28(17.4)$ & $133(82.6)$ & 2.064 & $0.776-5.492$ & 0.147 \\
\hline Asbestosis (BKV 4103) & 389 & $84(21.6)$ & $305(78.4)$ & 0.986 & $0.480-2.027$ & 0.97 \\
\hline Lung asbestosis (BKV 4103) & 122 & $24(19.7)$ & $98(80.3)$ & 0.922 & $0.357-2.381$ & 0.867 \\
\hline $1 / 1$ and $1 / 2 \mathrm{ILO}$ & 66 & $16(24.2)$ & $50(75.8)$ & 0.761 & $0.260-2.223$ & 0.617 \\
\hline $2 / 1,2 / 2$ and $2 / 3$ ILO & 46 & $8(17.4)$ & $38(82.6)$ & 1.133 & $0.342-3.757$ & 0.838 \\
\hline $3 / 2,3 / 3$ and $3 /+$ ILO & 9 & $0(0.0)$ & $9(100.0)$ & - & - & - \\
\hline Lung fibrosis of other aetiology & 55 & $14(25.5)$ & $41(74.5)$ & 0.903 & $0.366-2.227$ & 0.825 \\
\hline Malignant mesothelioma & 34 & $6(17.6)$ & $27(79.4)$ & 1.726 & $0.541-5.508$ & 0.356 \\
\hline Lung cancer (LC) & 364 & $84(23.1)$ & $280(76.9)$ & 1.165 & $0.565-2.399$ & 0.679 \\
\hline Asbestos induced LC (BKV 4104) & 49 & $13(26.5)$ & $36(73.5)$ & 1.239 & $0.389-3.946$ & 0.717 \\
\hline LC of other aetiology & 315 & $71(22.5)$ & $244(77.5)$ & 1.167 & $0.56-2.434$ & 0.68 \\
\hline
\end{tabular}

Data adjusted for the pack years (PY), gender and age (years) were used to calculate the odds ratios (OR) for the IL-10 G-1082A polymorphism in patients of the investigated groups compared to the healthy controls. OR analyses were performed for the more frequent genotypes (G-1082G) vs. the genotypes carrying at least one of the less frequent (A) allele (G-1082A or A-1082A).

Table VII. Adjusted odds ratio of IL-1 $\beta$ C-511T polymorphisms.

\begin{tabular}{|c|c|c|c|c|c|c|}
\hline \multirow[b]{2}{*}{ Diagnosis } & \multirow[b]{2}{*}{$\mathrm{n}$} & \multicolumn{2}{|c|}{ Genotype, n (\%) } & \multicolumn{3}{|c|}{ Multivariate analysis } \\
\hline & & $\mathrm{CC}$ & CT or TT & OR & $95 \% \mathrm{CI}$ & p-value \\
\hline Lung fibrosis & 605 & $281(46.4)$ & $324(53.6)$ & 0.818 & $0.454-1.472$ & 0.502 \\
\hline Silicosis (BKV 4101) & 161 & $81(50.3)$ & $80(49.7)$ & 0.669 & $0.297-1.508$ & 0.332 \\
\hline Asbestosis (BKV 4103) & 389 & $173(44.5)$ & $216(55.5)$ & 0.946 & $0.502-1.786$ & 0.865 \\
\hline Lung asbestosis (BKV 4103) & 122 & $53(43.4)$ & $69(56.6)$ & 0.861 & $0.376-1.971$ & 0.723 \\
\hline $1 / 1$ and $1 / 2$ ILO & 66 & $35(53.0)$ & $31(47.0)$ & 0.694 & $0.268-1.8$ & 0.453 \\
\hline $2 / 1,2 / 2$ and $2 / 3$ ILO & 46 & $15(32.6)$ & $31(67.4)$ & 1.293 & $0.462-3.615$ & 0.624 \\
\hline $3 / 2,3 / 3$ and $3 /+$ ILO & 9 & $3(33.3)$ & $6(66.7)$ & 3.583 & $0.271-47.47$ & 0.333 \\
\hline Lung fibrosis of other aetiology & 55 & $27(49.1)$ & $28(50.9)$ & 0.854 & $0.382-1.911$ & 0.701 \\
\hline Malignant mesothelioma & 34 & $14(41.2)$ & $20(58.8)$ & 1.28 & $0.491-3.334$ & 0.614 \\
\hline Lung cancer (LC) & 364 & $185(50.8)$ & $179(49.2)$ & 0.597 & $0.317-1.125$ & 0.11 \\
\hline Asbestos induced LC (BKV 4104) & 49 & $23(46.9)$ & $26(53.1)$ & 0.975 & $0.357-2.664$ & 0.961 \\
\hline LC of other aetiology & 315 & $162(51.4)$ & $153(48.6)$ & 0.534 & $0.279-1.024$ & 0.059 \\
\hline
\end{tabular}

Data adjusted for the pack years (PY), gender and age (years) were used to calculate the odds ratios (OR) for the IL-1 $\beta$ C-511T polymorphism in patients of the investigated groups compared to the healthy controls. OR analyses were performed for the more frequent genotypes $(\mathrm{C}-511 \mathrm{C})$ vs. the genotypes carrying at least one of the less frequent (T) allele (T-511C or T-511T).

The OR analyses were performed for the more frequent genotypes $(\mathrm{C}+3954 \mathrm{C}$ and $\mathrm{C}-511 \mathrm{C})$ vs. the genotypes carrying at least one of the less frequent $(\mathrm{T})$ allele $(\mathrm{C}+3954 \mathrm{~T}$ or $\mathrm{T}+3954 \mathrm{~T}$ and C-511T or T-511T). Data was adjusted for PY, age (years) and gender.

Patients carrying at least one less frequent $(\mathrm{T})$ allele of the IL-1 $\beta$-511 polymorphism showed decreased risk for fibrotic and malignant lung diseases $\left(\mathrm{OR}_{\text {asbestosis }}, 0.946\right.$; 95\% CI, 0.501.79; $\mathrm{OR}_{\text {silicosis }}, 0.67 ; 95 \% \mathrm{CI}, 0.30-1.51$ and $\mathrm{OR}_{\mathrm{LC}}, 0.597$; 95\% CI, 0.32-1.13) but not for malignant mesothelioma $\left(\mathrm{OR}_{\mathrm{MM}}, 1.28 ; 95 \% \mathrm{CI}, 0.49-3.33\right)$. Rather an increasing risk was seen for severe lung asbestosis (2/1, 2/2 and 2/3 ILO: OR, 1.29; 95\% CI, 0.46-3.62; 3/1, 3/2 and 3/+ ILO: OR, 3.583; 95\% CI, 0.27-47.47) (Table VII). 
Table VIII. Adjusted odds ratio of IL-1 $\beta$ C $+3954 \mathrm{~T}$ polymorphisms.

\begin{tabular}{|c|c|c|c|c|c|c|}
\hline \multirow[b]{2}{*}{ Diagnosis } & \multirow[b]{2}{*}{$\mathrm{n}$} & \multicolumn{2}{|c|}{ Genotype, n (\%) } & \multicolumn{3}{|c|}{ Multivariate analysis } \\
\hline & & $\mathrm{CC}$ & $\mathrm{CT}$ or TT & OR & $95 \% \mathrm{CI}$ & p-value \\
\hline Lung fibrosis & 605 & $343(56.7)$ & $262(43.3)$ & 0.915 & $0.508-1.647$ & 0.766 \\
\hline Silicosis (BKV 4101) & 161 & $82(50.9)$ & $79(49.1)$ & 1.175 & $0.525-2.63$ & 0.694 \\
\hline Asbestosis (BKV 4103) & 389 & $228(58.6)$ & $161(41.4)$ & 0.836 & $0.443-1.577$ & 0.58 \\
\hline Lung asbestosis (BKV 4103) & 122 & $66(54.1)$ & $56(45.9)$ & 1.113 & $0.489-2.533$ & 0.798 \\
\hline $1 / 1$ and $1 / 2$ ILO & 66 & 29 (43.9) & $37(56.1)$ & 1.789 & $0.69-4.641$ & 0.232 \\
\hline $2 / 1.2 / 2$ and $2 / 3$ ILO & 46 & $32(69.6)$ & $14(30.4)$ & 0.594 & $0.21-1.681$ & 0.326 \\
\hline $3 / 2.3 / 3$ and $3 /+$ ILO & 9 & $4(44.4)$ & $5(55.6)$ & 0.973 & $0.087-10.92$ & 0.982 \\
\hline Lung fibrosis of other aetiology & 55 & $33(60.0)$ & $22(40.0)$ & 0.828 & $0.37-1.857$ & 0.648 \\
\hline Malignant mesothelioma & 34 & $19(55.9)$ & $15(44.1)$ & 1.17 & $0.454-3.012$ & 0.746 \\
\hline Lung cancer (LC) & 364 & $207(56.9)$ & $157(43.1)$ & 1.108 & $0.588-2.087$ & 0.751 \\
\hline Asbestos induced LC (BKV 4104) & 49 & $27(55.1)$ & $22(44.9)$ & 1.272 & $0.467-3.466$ & 0.638 \\
\hline LC of other aetiology & 315 & $180(57.1)$ & $135(42.9)$ & 1.055 & $0.553-2.013$ & 0.871 \\
\hline
\end{tabular}

Data adjusted for the pack years (PY), gender and age (years) were used to calculate the odds ratios (OR) for the IL- $1 \beta \mathrm{C}+3954 \mathrm{~T}$ polymorphism in patients of the investigated groups compared to the healthy controls. OR analyses were performed for the more frequent genotypes $(\mathrm{C}+3954 \mathrm{C})$ vs. the genotypes carrying at least one of the less frequent $(\mathrm{T})$ allele $(\mathrm{C}+3954 \mathrm{~T}$ or $\mathrm{T}+3954 \mathrm{~T})$.

This analysis revealed that patients carrying at least one $\mathrm{T}$ allele of the IL- $1 \beta+3954$ polymorphism were at higher risk for moderate lung asbestosis (1/1 and 1/2 ILO: OR, 1.79; 95\% CI, 0.69-4.64) as well as for hyaline pleural plaques (OR, $1.44 ; 95 \% \mathrm{CI}, 0.6-3.5)$. Additionally, a higher risk was seen in the asbestos-induced lung cancer patients $\left(\mathrm{OR}_{\mathrm{LC} \text { asbestos }}, 1.27\right.$; 95\% CI, 0.47-3.47) rather than in lung cancer of other aetiology $\left(\mathrm{OR}_{\mathrm{LC} \text { other atiology }}, 1.055 ; 95 \% \mathrm{CI}, 0.55-2.01\right)$ (Table VIII). Significance could not be gained in the described results.

\section{Discussion}

Pneumoconiosis, such as asbestosis or silicosis are occupational lung diseases caused by inhaled dust particles. Among others, cytokines such as TNF- $\alpha$, TGF- $\beta$, IL- $1 \beta$, IL- 6 or IL-10 play an important role in the pathogenesis of pneumoconiosis $(1,30-33)$. Coal dust exposure stimulates inflammatory response leading to increased release of IL-1 (5). In previous studies we described an association of TNF- $\alpha$ (34) and TGF- $\beta$ (35) polymorphisms with asbestos induced diseases. Since interleukins play an important role in inflammatory processes, genetic factors of these genes could also modify the susceptibility of asbestos or silica-related diseases.

Our results did not show any association with the IL-1 $\beta$ (+3954) or IL-1ß (-511) polymorphism. Also Yucesoy et al (36) did not find any association of the IL-1 $\beta(+3954)$ polymorphism with silicosis. In contrast a higher risk of lung cancer (OR, 5.45; 95\% CI, 2.75-4.42) was reported for T-allele carriers in the Japanese population (37).

Inflammatory cytokines TNF- $\alpha$, IL- 1 and IL- 6 are released during inflammation. IL- 6 then shows anti-inflammatory effects by inhibiting the secretion of TNF- $\alpha$ and IL- 1 . Therefore IL-6 is a pro- and anti-inflammatory cytokine (38). The $-174 \mathrm{C}$ allele of IL-6 was associated with a lower basal expression, which persisted also after stimulation with LPS or IL-1. Significant lower plasma level of IL-6 in healthy subjects was associated with the $-174 \mathrm{C}$ allele (22). This study did not detect any significant effect of the IL-6 $(-174 \mathrm{G} / \mathrm{C})$ polymorphism in a cohort of 1180 subjects. A tendency for a higher risk of C-allele carriers for fibrotic lung diseases, malignant mesothelioma or asbestosinduced lung cancer was noted. A significant association of the GG homozygous genotype with an improved survival in sepsis has been previously described (39). In contrast, a protective effect of the IL-6 variant was found on the development and severity of coal workers' pneumoconiosis in Turkey (40).

IL-10 as an anti-inflammatory cytokine inhibits the release of proinflammatory mediators, such as TNF- $\alpha$, IL- $1 \beta$ and IL-6 (23). Genotypes carrying the IL-10 -1082A allele are associated with a lower IL-10 production (41-43). Our study revealed, that patients carrying at least one A allele are at lower risk for asbestosis or fibrotic lung diseases of other aetiology, but at higher risk for malignant mesothelioma. Significant higher risk for chronic obstructive pulmonary disease (COPD) (OR, 1.66; 95\% CI, 1.01-2.75; $\mathrm{P}=0.0046)$ and small-cell lung cancer (SCLC) (OR, 3.01; 95\% CI, 1.21-7.48; $\mathrm{P}=0.0006)$ was detected in German -1082G-allele carriers (44). Higher ORs (OR, 5.26; 95\% CI, 2.65-10.4; $\mathrm{P}<0.0001)$ were observed for non-small cell lung cancer (NSCLC) in Chinese patients carrying the IL-10 -1082G allele (45). A higher frequency of the IL-10 -1082G allele was reported in Chinese patients with cardia gastric cancer (46). Worth noting is the fact that the $-174 \mathrm{C}$ allele of IL- 6 and the $-1082 \mathrm{~A}$ allele of IL-10 have opposite effects regarding fibrotic lung diseases.

This study did not reveal sufficient evidence for an association of the investigated interleukin polymorphisms with asbestos or silica-induced diseases. Since the system of carcinogenesis/fibrogenesis is very complex, the changes caused by one SNP may not have enough impact to reveal significance. 
Therefore, it appears to be important and appropriate to undertake more studies with new methods, to analyse combination effects and the multifaceted interactions between genetic and environmental factors (47).

\section{Acknowledgements}

Some of the results are included in the thesis of $\mathrm{J}$. Wübbeling.

\section{References}

1. Kamp DW: Asbestos-induced lung diseases: an update. Transl Res 153: 143-152, 2009.

2. Schneider J, Arhelger R and Hauser-Heidt G: Wertigkeit der statischen Compliance-Messung bei Asbestfaserstaub-verursachten Erkrankungen der Lunge und der Pleura. Wissenschaftlicher Abschlußbericht pp1-79, 2006 (In German).

3. Manning CB, Vallyathan V and Mossman BT: Diseases caused by asbestos: mechanisms of injury and disease development. Int Immunopharmacol 2: 191-200, 2002.

4. Dostert C, Petrilli V, Van Bruggen R, Steele C, Mossman BT and Tschopp J: Innate immune activation through Nalp3 inflammasome sensing of asbestos and silica. Science 320: 674-677, 2008.

5. Ates I, Yucesoy B, Yucel A, Suzen SH, Karakas Y and Karakaya A: Possible effect of gene polymorphisms on the release of TNF alpha and IL1 cytokines in coal workers' pneumoconiosis. Exp Toxicol Pathol 63: 175-179, 2011.

6. Weber A, Wasiliew P and Kracht M: Interleukin-1 (IL-1) pathway (Review). Sci Signal 3: cm1, 2010.

7. Weber A, Wasiliew P and Kracht M: Interleukin-1beta (IL-1beta) processing pathway (Review). Sci Signal 3: cm2, 2010.

8. Voronov E, Shouval DS, Krelin Y, et al: IL-1 is required for tumor invasiveness and angiogenesis. Proc Natl Acad Sci USA 100: 2645-2650, 2003.

9. Krelin Y, Voronov E, Dotan S, et al: Interleukin-1beta-driven inflammation promotes the development and invasiveness of chemical carcinogen-induced tumors. Cancer Res 67: 1062-1071, 2007.

10. Elaraj DM, Weinreich DM, Varghese S, et al: The role of interleukin 1 in growth and metastasis of human cancer xenografts. Clin Cancer Res 12: 1088-1096, 2006.

11. Bhattacharya K, Dopp E, Kakkar P, et al: Biomarkers in risk assessment of asbestos exposure. Mutat Res 579: 6-21, 2005.

12. Luster MI and Simeonova PP: Asbestos induces inflammatory cytokines in the lung through redox sensitive transcription factors. Toxicol Lett 102-103: 271-275, 1998.

13. Zhai R, Liu G, Ge X, et al: Serum levels of tumor necrosis factor-alpha (TNF-alpha), interleukin 6 (IL-6), and their soluble receptors in coal workers' pneumoconiosis. Respir Med 96: 829-834, 2002

14. Houssiau FA, Devogelaer JP, Van Damme J, de Deuxchaisnes CN and Van Snick J: Interleukin-6 in synovial fluid and serum of patients with rheumatoid arthritis and other inflammatory arthritides. Arthitis Rheum 31: 784-788, 1988.

15. Trevilatto PC, Scarel-Caminaga RM, de Brito RB Jr, de Souza AP and Line SR: Polymorphism at position -174 of IL-6 gene is associated with susceptibility to chronic periodontitis in a Caucasian Brazilian population. J Clin Periodontol 30: 438-442, 2003.

16. Grossman RM, Krueger J, Yourish D, et al: Interleukin 6 is expressed in high levels in psoriatic skin and stimulates proliferation of cultured human keratinocytes. Proc Natl Acad Sci USA 86: 6367-6371, 1989

17. Bidwell J, Keen L, Gallagher G, et al: Cytokine gene polymorphism in human disease: on-line databases. Genes Immun 1: 3-19, 1999.

18. Bidwell J, Keen L, Gallagher G, et al: Cytokine gene polymorphism in human disease: on-line databases, supplement 1 . Genes Immun 2: 61-70, 2001.

19. Hollegaard MV and Bidwell JL: Cytokine gene polymorphism in human disease: on-line databases, Supplement 3. Genes Immun 7: 269-276, 2006.

20. Hall SK, Perregaux DG, Gabel CA, et al: Correlation of polymorphic variation in the promoter region of the interleukin-1 beta gene with secretion of interleukin-1 beta protein. Arthritis Rheum 50: 1976-1983, 2004.
21. Pociot F, Molvig J, Wogensen L, Worsaae H and Nerup J: A TaqI polymorphism in the human interleukin-1 beta (IL-1 beta) gene correlates with IL-1 beta secretion in vitro. Eur J Clin Invest 22: 396-402, 1992.

22. Fishman D, Faulds G, Jeffery R, et al: The effect of novel polymorphisms in the interleukin-6 (IL-6) gene on IL-6 transcription and plasma IL-6 levels, and an association with systemic-onset juvenile chronic arthritis. J Clin Invest 102: 1369-1376, 1998.

23. Sabat R, Grutz G, Warszawska K, et al: Biology of interleukin-10. Cytokine Growth Factor Rev 21: 331-344, 2010.

24. Moore KW, de Waal Malefyt R, Coffman RL and O'Garra A: Interleukin-10 and the interleukin-10 receptor. Annu Rev Immunol 19: 683-765, 2001.

25. Suarez A, Castro P, Alonso R, Mozo L and Gutierrez C: Interindividual variations in constitutive interleukin-10 messenger RNA and protein levels and their association with genetic polymorphisms. Transplantation 75: 711-717, 2003.

26. American Thoracic Society. Idiopathic pulmonary fibrosis: diagnosis and treatment. International consensus statement. American Thoracic Society (ATS), and the European Respiratory Society (ERS). Am J Respir Crit Care Med 161: 646-664, 2000.

27. American Thoracic Society/European Respiratory Society International Multidisciplinary Consensus Classification of the Idiopathic Interstitial Pneumonias. This joint statement of the American Thoracic Society (ATS), and the European Respiratory Society (ERS) was adopted by the ATS board of directors, June 2001 and by the ERS Executive Committee, June 2001. Am J Respir Crit Care Med 165: 277-304, 2002.

28. Travis WD (ed): Tumours of the Lung, Pleura, Thymus and Heart. IARC Press, Lyon, pp9-56, 2004.

29. Hering KG, Jacobsen M, Bosch-Galetke E, et al: Further development of the International Pneumoconiosis Classification - from ILO 1980 to ILO 2000 and to ILO 2000/German Federal Republic version. Pneumologie 57: 576-584, 2003 (In German).

30. Mossman BT and Churg A: Mechanisms in the pathogenesis of asbestosis and silicosis. Am J Respir Crit Care Med 157: 1666-1680, 1998.

31. Nymark P, Wikman H, Hienonen-Kempas T and Anttila S: Molecular and genetic changes in asbestos-related lung cancer. Cancer Lett 265: 1-15, 2008.

32. Sanceau J, Wijdenes J, Revel M and Wietzerbin J: IL-6 and IL-6 receptor modulation by IFN-gamma and tumor necrosis factoralpha in human monocytic cell line (THP-1). Priming effect of IFN-gamma. J Immunol 147: 2630-2637, 1991.

33. Huaux F, Arras M, Vink A, Renauld JC and Lison D: Soluble tumor necrosis factor (TNF) receptors p55 and p75 and interleukin-10 downregulate TNF-alpha activity during the lung response to silica particles in NMRI mice. Am J Respir Cell Mol Biol 21: 137-145, 1999.

34. Helmig S, Aliahmadi $\mathrm{N}$ and Schneider J: Tumour necrosis factor-alpha gene polymorphisms in asbestos-induced diseases. Biomarkers 15: 400-409, 2010.

35. Helmig S, Belwe A and Schneider J: Association of transforming growth factor betal gene polymorphisms and asbestos-induced fibrosis and tumors. J Investig Med 57: 655-661, 2009.

36. Yucesoy B, Vallyathan V, Landsittel DP, Simeonova P and Luster MI: Cytokine polymorphisms in silicosis and other pneumoconioses. Mol Cell Biochem 234-235: 219-224, 2002.

37. Kiyohara C, Horiuchi T, Takayama K and Nakanishi Y: IL1B rs1143634 polymorphism, cigarette smoking, alcohol use, and lung cancer risk in a Japanese population. J Thorac Oncol 5: 299-304, 2010

38. Papanicolaou DA, Wilder RL, Manolagas SC and Chrousos GP: The pathophysiologic roles of interleukin- 6 in human disease. Ann Intern Med 128: 127-137, 1998.

39. Schluter B, Raufhake C, Erren M, et al: Effect of the interleukin-6 promoter polymorphism $(-174 \mathrm{G} / \mathrm{C})$ on the incidence and outcome of sepsis. Crit Care Med 30: 32-37, 2002.

40. Ates I, Suzen HS, Yucesoy B, Tekin IO and Karakaya A: Association of cytokine gene polymorphisms in CWP and its severity in Turkish coal workers. Am J Ind Med 51: 741-747, 2008.

41. Turner DM, Williams DM, Sankaran D, Lazarus M, Sinnott PJ and Hutchinson IV: An investigation of polymorphism in the interleukin-10 gene promoter. Eur J Immunogenet 24: 1-8, 1997.

42. Tambur AR, Ortegel JW, Ben-Ari Z, et al: Role of cytokine gene polymorphism in hepatitis $\mathrm{C}$ recurrence and allograft rejection among liver transplant recipients. Transplantation 71: 1475-1480, 2001 . 
43. Perrey C, Pravica V, Sinnott PJ and Hutchinson IV: Genotyping for polymorphisms in interferon-gamma, interleukin-10, transforming growth factor-beta 1 and tumour necrosis factor-alpha genes: a technical report. Transpl Immunol 6: 193-197, 1998.

44. Seifart C, Plagens A, Dempfle A, et al: TNF-alpha, TNF-beta, IL-6, and IL-10 polymorphisms in patients with lung cancer. Dis Markers 21: 157-165, 2005.

45. Shih CM, Lee YL, Chiou HL, et al: The involvement of genetic polymorphism of IL-10 promoter in non-small cell lung cancer. Lung Cancer 50: 291-297, 2005.

46. Zhou Y, Hu W, Zhuang W and Wu X: Interleukin-10 -1082 promoter polymorphism and gastric cancer risk in a Chinese Han population. Mol Cell Biochem 347: 89-93, 2010.
47. Silverman EK and Palmer LJ: Case-control association studies for the genetics of complex respiratory diseases. Am J Respir Cell Mol Biol 22: 645-648, 2000.

48. Parker J: Radiological criteria: the use of chest imaging techniques in asbestos-related diseases. In: Proceedings of an International Expert Meeting on Asbestos, Asbestosis and Cancer, People and Work, Research Reports. Finnish Institute of Occupational Health. Helsinki, pp28-40, 1997.

49. DeVuyst P: Guidelines for attribution of lung cancer to asbestos. In: Proceedings of an International Expert Meeting on Asbestos, Asbestosis and Cancer, People and Work, Research Reports. Finnish Institute of Occupational Health. Helsinki, pp92-96, 1997. 